\title{
Zonal variation in leaf-litter decomposition in a secondary mangrove forest
}

\author{
Vilanee Suchewaboripont ${ }^{1}$, Sasitorn Poungparn ${ }^{1, *}$ and Pipat Patanaponpaiboon ${ }^{1}$ \\ ${ }^{1}$ Department of Botany, Faculty of Science, Chulalongkorn University, Bangkok, 10330, Thailand. \\ "Corresponding author: Sasitorn. P@chula. ac.th
}

\begin{abstract}
Leaf-litter decomposition was examined from November 2008 to October 2009 using litter bags in a secondary mangrove forest along the Trat River, eastern Thailand. The study site exhibited three distinct vegetation zones (dominated by Avicennia, Rhizophora, and Xylocarpus spp.) moving inland from the river edge. The decomposition rates $(K)$, indicated by a negative exponential curve, were numerically ranked with the highest, Avicennia (0.023), at the river edge and decreasing as heading inland through the Rhizophora (0.020) zone to the lowest decomposition rate at the most inland Xylocarpus zone (0.014). They were similar to previously reported values for mangrove forests. The amount of residual leaf litter in the Avicennia and Rhizophora zones decreased rapidly during the first 112 days of the trial, whereas that in the Xylocarpus zone decreased more slowly. Over the remainder of the trial period (total of 362 days), residual leaf litter slowly declined. At the end of the trial, the weight of leaf litter lost was highest in the Avicennia zone, followed by the Xylocarpus and Rhizophora zones. Correspondingly, the $\mathrm{C} / \mathrm{N}$ ratio of the residual leaf litter decreased rapidly over the first 54 days of exposure time in all three zones, and then stabilized to a slow change after 112 days of exposure onwards. Differences in the amount of leaf litter lost were discussed in terms of causative physical factors such as inundation period and soil temperature. The soil temperature at a depth of $10 \mathrm{~cm}$ below the surface was highest in the Avicennia zone and decreased with increasing distance from the river edge. The relative elevation of the forest floor in the Avicennia zone at the river edge resulted in the longest period of inundation, which, along with high soil temperature, promoted the decomposition of leaf litter. Additionally, we mentioned the contribution of $\mathrm{CO}_{2}$ released from litter decomposition through soil respiration of the mangrove forest.
\end{abstract}

Key words: decomposition, leaf litter, mangrove zonation

\section{INTRODUCTION}

Litter decomposition is an important component of the dynamics of forest nutrient cycling (Lugo and Snedaker 1974, Twilley et al. 1986, Kurz et al. 2000, Zhou et al. 2008). Ecosystems with low rates of decomposition tend to slowly release carbon from the litter into the atmosphere as carbon dioxide $\left(\mathrm{CO}_{2}\right)$ and thus act as carbon sinks. Generally, litter decomposition in terrestrial forests is regulated by environmental factors, such as the season (Liu et al. 2005) and interrelated temperatures (Valiela et al. 1985, Hoq et al. 2002, Moretto and Distel 2003, Liu et al. 2005). Specific characteristics of a forest ecosystem, such as the quality and species of litter (Alhamd et al. 2004, Zhou et al. 2008), may also affect the litter decomposition process.

Mangrove ecosystems are usually located in estuaries or in riverine areas penetrated by sea water. The influence of the frequency and level of the daily tide is considered a unique characteristic of this ecosystem. In addition, vegetative zonation, i.e., changes in the dominant tree species moving inland from the sea or river edge, is a unique feature commonly found in mangrove forests (Watson 1928, Macnae 1967). Indeed, plant succession and adaptation to some of the environmental gradients across the intertidal zone may lead to mangrove zonation (Smith 1992). Several studies have documented such mangrove zonation in Thailand (e.g., Aksornkoae 1975, Aksornkoae 1976, Patanaponpaiboon 1979).

Leaf-litter decomposition in mangrove ecosystems has been examined in relation to relevant physical factors such as tidal inundation (Twilley et al. 1986, Robertson 1988, Boulton and Boon 1991, Imgraben and Dittmann 2008) and temperature (Mackey and Smail 1996). These studies have demonstrated that leaf litter is rapidly decomposed in the lower intertidal zone (Mackey and Smail 1996, Dick and Osunkoya 2000, Middleton and McKee 2001, Bosire et al. 2005). Several previous studies 
have examined leaf-litter decomposition in the vegetation of mangrove forests in Thailand (Aksornkoae and Khemnark 1980, Angsupanich and Aksornkoae 1994); however, the causative physical factors of rates of leaflitter decomposition have rarely been explained.

This study reported here therefore aimed to investigate the rates of leaf-litter decomposition using the litter-bag method in the respective different vegetation zones of a secondary mangrove forest. We hypothesized that zonal variation of decomposition rate of leaf litter was affected by the physical factors of inundation time and soil temperature.

\section{MATERIALS AND METHODS}

\section{Study site}

The study site was located in a secondary mangrove forest along the Trat River, Trat Province, eastern Thailand (Fig. 1). Since the 1980s, when timber and charcoal production at the site ceased, the forest has been managed by the Mangrove Forest Learning and Development Center No. 1 of the Department of Marine

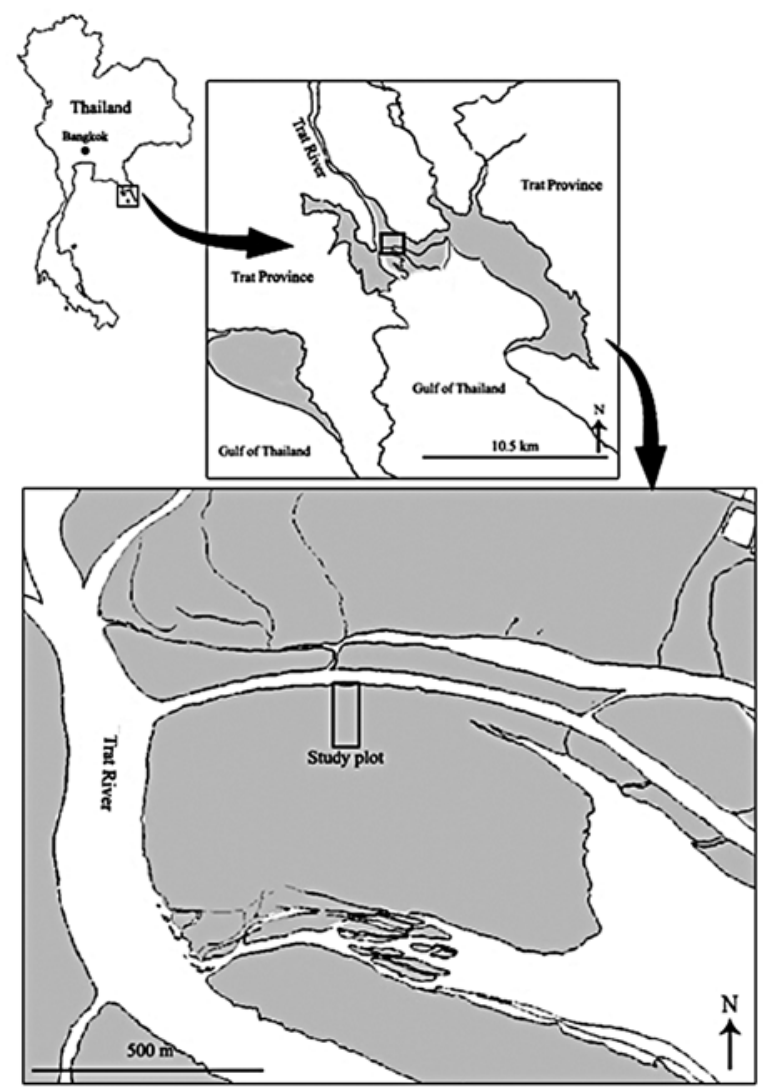

Fig. 1. Study site located on an estuary of the Trat River, Trat Province, Thailand. The gray area is mangrove forest. and Coastal Resources. The average (mean \pm SD) of annual precipitation and temperature during 2005-2008 were $5172 \pm 875 \mathrm{~mm}$ and $27.5 \pm 0.6^{\circ} \mathrm{C}$, respectively (Department of Meteorology, Thailand).

At the site, a $50 \times 120$-m study plot was established. In the plot, the average density of trees with a diameter at breast height (dbh) of $>4.5 \mathrm{~cm}$ was 1890 trees ha ${ }^{-1}$, with a mean $\mathrm{dbh}$ and height of $11.3 \mathrm{~cm}$ and $13.7 \mathrm{~m}$, respectively. Based on the dominant tree species (Table 1), the mangrove forest was clearly separated into three vegetation zones moving inland from the river edge (Fig. 2). At the river fringe, Sonneratia caseolaris was dominant in a narrow belt, and a broader mature stand of Avicennia $a l b a$ was distributed over the landward zone, hereafter

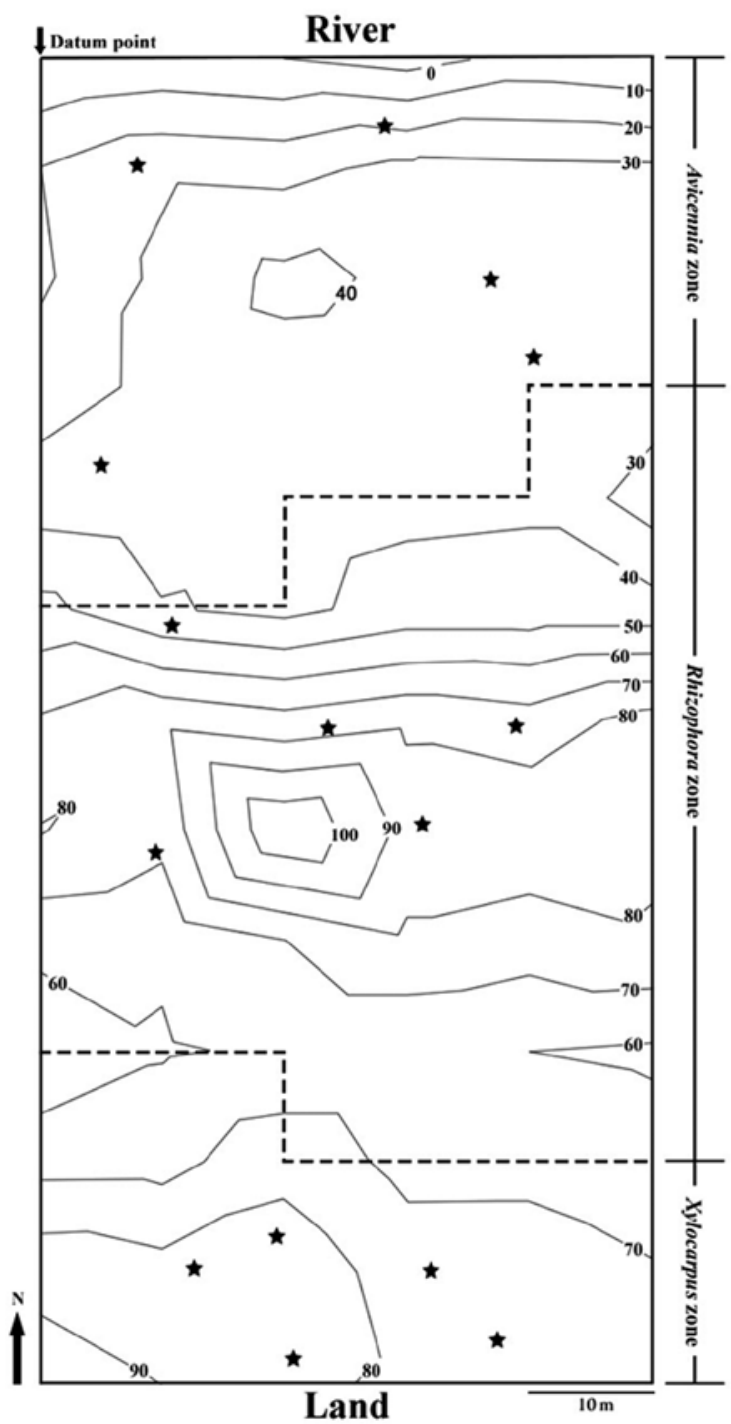

Fig. 2. The study plot, showing $10-\mathrm{m}$ contour lines and the vegetation zones. Fifteen litter-bags were placed at each of the five positions (indicated by stars) in each zone. 
Table 1. The composition, density, average tree height (h), and diameter at breast height (dbh) of the three distinct vegetation zones in the mangrove forest study site at Trat River, Thailand. Values are means \pm standard deviation

\begin{tabular}{|c|c|c|c|c|c|c|c|c|c|}
\hline \multirow{3}{*}{ Species } & \multicolumn{3}{|c|}{ Avicennia zone } & \multicolumn{3}{|c|}{ Rhizophora zone } & \multicolumn{3}{|c|}{ Xylocarpus zone } \\
\hline & density & $\mathrm{dbh}$ & $\mathrm{h}$ & density & $\mathrm{dbh}$ & $\mathrm{h}$ & density & $\mathrm{dbh}$ & $\mathrm{h}$ \\
\hline & $\left(\right.$ trees ha $\left.^{-1}\right)$ & $(\mathrm{cm})$ & $(\mathrm{m})$ & $\left(\right.$ trees ha $\left.^{-1}\right)$ & $(\mathrm{cm})$ & (m) & $\left(\right.$ trees ha $\left.^{-1}\right)$ & $(\mathrm{cm})$ & $(\mathrm{m})$ \\
\hline Avicennia alba & 476.2 & $15.6 \pm 10.8$ & $14.1 \pm 7.1$ & 44.4 & $31.2 \pm 15.8$ & $23.3 \pm 7.6$ & - & - & \\
\hline Bruguiera gymnorrhiza & - & - & - & 63.0 & $10.3 \pm 4.4$ & $10.7 \pm 3.6$ & 283.3 & $8.1 \pm 4.9$ & $8.7 \pm 3.7$ \\
\hline Bruguiera sexangula & - & - & - & 14.8 & $14.0 \pm 5.8$ & $13.7 \pm 4.7$ & 8.3 & $6.0 \pm 0.0$ & $6.9 \pm 0.0$ \\
\hline Ceriops tagal & - & - & - & 22.2 & $7.3 \pm 2.4$ & $8.1 \pm 2.3$ & 250.0 & $6.4 \pm 1.3$ & $7.2 \pm 1.3$ \\
\hline Heritiera littoralis & - & - & - & - & - & - & 16.7 & $12.1 \pm 3.1$ & $12.4 \pm 2.6$ \\
\hline Lumnitzera littorea & - & - & - & - & - & - & 8.3 & $7.6 \pm 0.0$ & $8.5 \pm 0.0$ \\
\hline Rhizophora apiculata & 500.0 & $8.4 \pm 2.8$ & $11.6 \pm 3.0$ & 1174.1 & $11.8 \pm 5.1$ & $15.0 \pm 4.8$ & 1450.0 & $8.5 \pm 2.9$ & $11.7 \pm 3.2$ \\
\hline Rhizophora mucronata & 57.1 & $11.9 \pm 4.0$ & $15.3 \pm 3.9$ & 385.2 & $10.6 \pm 3.9$ & $13.0 \pm 3.9$ & - & - & 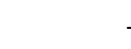 \\
\hline Sonneratia caseolaris & 71.4 & $21.0 \pm 9.4$ & $22.1 \pm 7.0$ & - & - & - & - & - & 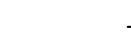 \\
\hline Xylocarpus granatum & - & - & - & 100.0 & $10.7 \pm 4.2$ & $13.9 \pm 4.2$ & 1441.7 & $10.6 \pm 6.3$ & $13.6 \pm 5.2$ \\
\hline
\end{tabular}

called the Avicennia zone. Conical pneumatophores were densely distributed over the silt loam soil of this zone. Adjacent to the inland region, the second forest zone (hereafter called the Rhizophora zone) was crowned by Rhizophora apiculata and $R$. mucronata that produced many stilt roots interwoven with each other in the silt loam soil. The last, most inland zone, hereafter the Xylocarpus zone, was dominated by Xylocarpus granatum with mixed species of Bruguiera gymnorrhiza, Ceriops tagal, and R. apiculata, and a high density of buttresses and knee roots on the sandy loam sediment.

\section{Measurement of physical factors}

Soil temperature was measured using temperature sensors and data loggers (TidbiT v2 Temp logger, Onset Computer Co., Ltd.). One sensor and one data logger were buried in the soil at $10 \mathrm{~cm}$ below the surface in each of the three (Avicennia, Rhizophora, and Xylocarpus) zones. To avoid outlying data from extreme sun exposure, temperature sensors and data loggers were buried in locations under a homogenous canopy. All sensors recorded data at 30-min intervals from November 2008 to October 2009. Another sensor measured the water temperature of the river in front of the study plot.

The inundation period for each zone was considered the period from when the tide began to move inland from the river edge until the water reached each zone. The time taken for the water front to recede to the river edge was also recorded. Both measures of tidal movement were conducted three times of spring and single tide: on 24 January and 11-12 March 2009 in the dry season and on 29 August 2009 during the wet season.

\section{Leaf decomposition experiment}

The evaluation of leaf decomposition was conducted using the litter-bag method as described elsewhere (Robertson 1988, Mackey and Smail 1996, Ashton et al. 1999, Imgraben and Dittmann 2008). Mixed senescent leaves (green/yellow color) on the forest floor were manually collected from throughout the study plot, washed in freshwater to remove sediment, and then airdried for $48 \mathrm{~h}$. The air-dried leaves were mixed thoroughly and weighed into approximately 15.0-g aliquots, each of which was accurately weighed and placed into a $25 \times 25-\mathrm{cm}$ nylon bag with a mesh size of 1.5 $\times 1.5 \mathrm{~mm}$. This mesh size is large enough to allow small sizes of macrobenthos (usually greater than $0.5 \mathrm{~mm}$ in size) to break the litter and prevented particulate organic matter from washing out of the bag (Imgraben and Dittmann 2008).

In total, 225 decomposition bags were prepared, 15 of which were placed on the soil surface at each of five sites in each of the three zones at the end of October 2008. These bags were laid out on the forest floor and securely tied to aerial roots to keep them in place. Five bags (one from each site) from each zone (15 in total) were sampled 14, 28, 41, 54, 82, 112, 139, 166, 195, 221, $251,277,307,333$, and 362 days after the beginning of the trial. The bags were washed to remove sediment, and the residual litter was oven-dried at $80^{\circ} \mathrm{C}$ to a constant weight to obtain dry weights.

To calculate the dry-to-fresh weight ratio, approximately $15.0 \mathrm{~g}$ of air-dried leaves (of known weight) were placed in the litter bags and oven dried at $80^{\circ} \mathrm{C}$ to a constant mass to obtain dry weights. This ratio was used 
to convert the initial fresh weight to dry weight of leaf litter. However, ash content of the remnants was not analyzed.

\section{Carbon/nitrogen $(\mathrm{C} / \mathrm{N})$ ratio analysis}

The residual leaf litter in the five decomposition bags for each zone was mixed into one composite sample to attain sufficient material for $\mathrm{C} / \mathrm{N}$ ratio analysis. These samples were ground to a powder using a mortar and pestle. Approximately $1.0 \mathrm{~g}$ of each ground sample, as well as ground samples from leaves at the start of the trial, was used for $\mathrm{C} / \mathrm{N}$ analysis using a TruSpec $\mathrm{CN}$ Analyzer (LECO Co. Ltd., USA).

\section{Statistical analysis}

Two-way analysis of variance (ANOVA) was used to test for the effects of vegetation zone and time on the amount of leaf litter lost. Differences in physical factors among zones were analyzed using one-way ANOVA. The correlations among the decay coefficient and physical factors (i.e., soil temperature and inundation time) were analyzed using Spearman's rank correlation. ANOVA and
Spearman's rank correlation were conducted using SPSS 14 for Windows software (SPSS Inc., USA).

The percentage of residual weight was fit through time for each zone using a negative exponential model (Olson 1963):

$$
Y_{t}=Y_{0} e^{-K t}
$$

where $Y_{t}$ is the percentage of residual weight after time $t$ (days), $Y_{0}$ is the percentage of the initial weight, and $K$ is a decay coefficient. The data were fit to the model using Graphpad PRISM version 5 software (GraphPad Software, Inc., USA), following Kurz et al. (2000) and Ananda et al. (2008).

\section{RESULTS}

\section{Physical factors}

The average daily soil temperature from November 2008 to October 2009 exhibited similar patterns of seasonal variation in the three vegetation zones (Fig. 3). Within each zone, the lowest temperature occurred in January 2009, and the highest temperature occurred in April (Fig. 3 ). However, the average daily soil temperature significantly differed among zones (ANOVA, $\mathrm{P}<0.001$ ).

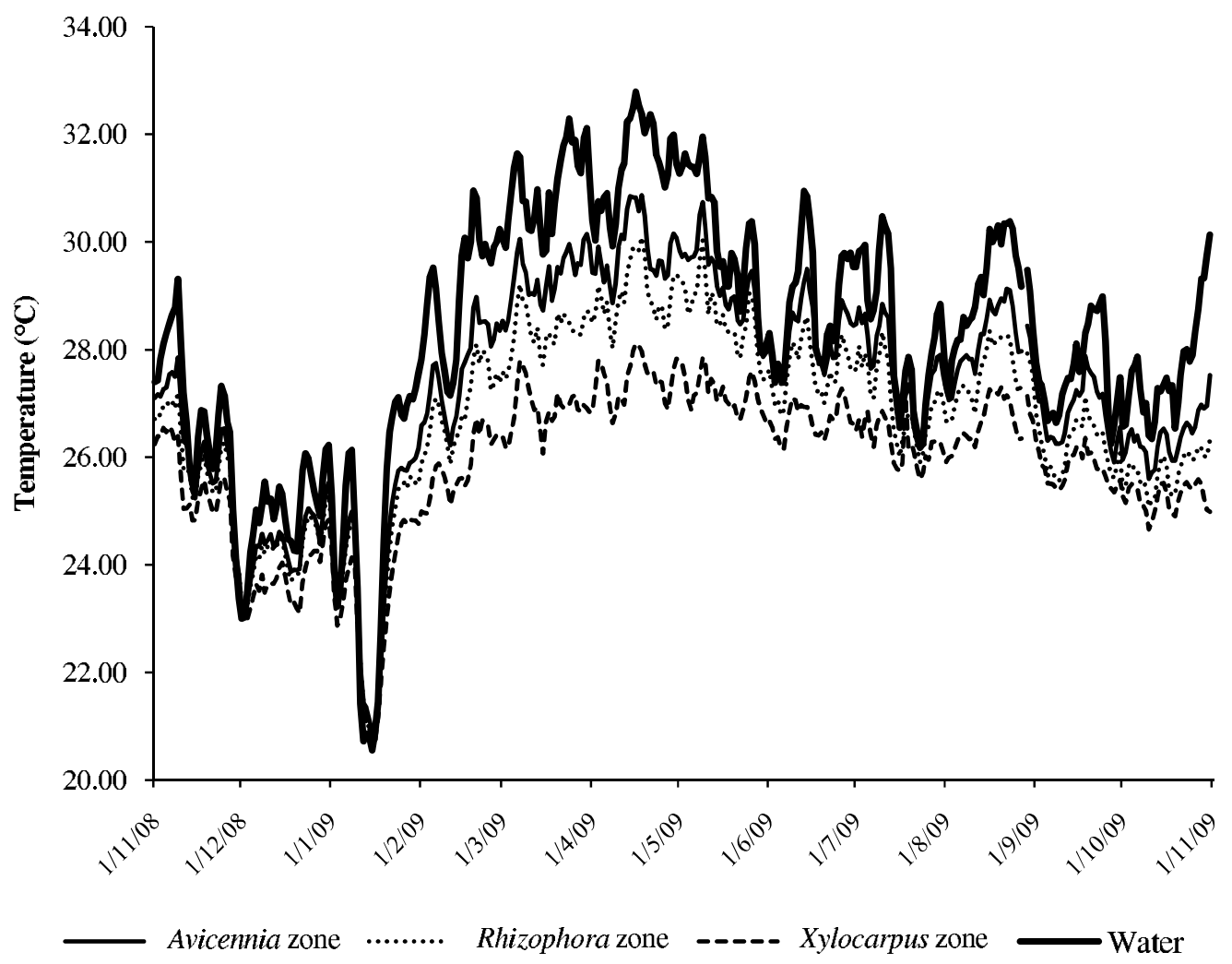

Fig. 3. Daily soil and water temperatures of the three zones from November 2008 to October 2009. Each data point is an average of 48 measurements. 
The highest daily soil temperature was observed in the Avicennia zone $\left(27.4 \pm 1.8^{\circ} \mathrm{C}\right)$, followed by the Rhizophora and Xylocarpus zones $\left(26.8 \pm 1.6\right.$ and $26.0 \pm 1.3^{\circ} \mathrm{C}$, respectively). Thus, the average soil temperature in this forest tended to decrease with increasing distance from the river edge (Fig. 3). The water temperature was average at $28.27 \pm 2.23^{\circ} \mathrm{C}$, and usually higher than the soil temperature (Fig. 3 ).

The lowest average period of inundation $(115 \pm 41$ min) occurred in the most inland Xylocarpus zone. This value was significantly lower than the average period of inundation in the other two zones: $302 \pm 53$ and $370 \pm 80$ min for the Rhizophora and Avicennia zones, respectively (ANOVA, $\mathrm{P}<0.01$ ); these values corresponded to the proximity of the zones to the river edge. The soil temperature was significantly correlated to inundation period (Spearman's rank; $r=0.99, \mathrm{n}=3, \mathrm{P}<0.01$ ).

\section{Leaf-litter decomposition}

The amount of leaf litter lost varied significantly over time (two-way ANOVA, $\mathrm{F}_{14,225}=49.2, \mathrm{P}<0.001$ ) in all zones. The amount of residual leaf litter in the Avicennia and Rhizophora zones rapidly decreased during the first 112 days of the trial, losing an average mass (as a proportion of the original starting amount) of $90.6 \pm 9.5 \%$ and $82.2 \pm$ $15.2 \%$, respectively. In the Xylocarpus zone, the amount of leaf litter also rapidly decreased during the first 112 days of the trial $(74.5 \pm 11.9 \%)$ but at a lower rate of loss and with a slower decrease in this rate compared to those for the other two zones (Fig. 4). Subsequently, leaf litter in the Rhizophora zone decreased slightly with time until the end of the 362-day trial (Fig. 4), ultimately losing $94.5 \pm$ $6.65 \%$. However, the amount of leaf litter lost in the Avicennia and Xylocarpus zones reached $99.2 \pm 1.12 \%$ and $97.8 \pm 2.21 \%$ by the end of the trial. The amount of leaf litter lost significantly differed across zones (two-way ANOVA, $\left.\mathrm{F}_{2,225}=11.1, \mathrm{P}<0.001\right)$; however, the interaction between zone and time was not significant (two-way ANOVA, $\mathrm{F}_{28,225}=0.665, \mathrm{P}=0.899$ ).

The average residual leaf litter across time was fit for each vegetation zone using equation 1 (Fig. 4), revealing a significant $(\mathrm{P}<0.01)$ exponential relationship for all zones. The decay coefficient $(K)$, or decomposition rate based on the regression line, was highest in the Avicennia zone at $0.023\left(\mathrm{R}^{2}=0.981\right)$, followed by the Rhizophora and Xylocarpus zones at $0.020\left(\mathrm{R}^{2}=0.984\right)$ and $0.014\left(\mathrm{R}^{2}=0.981\right)$, respectively. The positive correlations between the leaf-

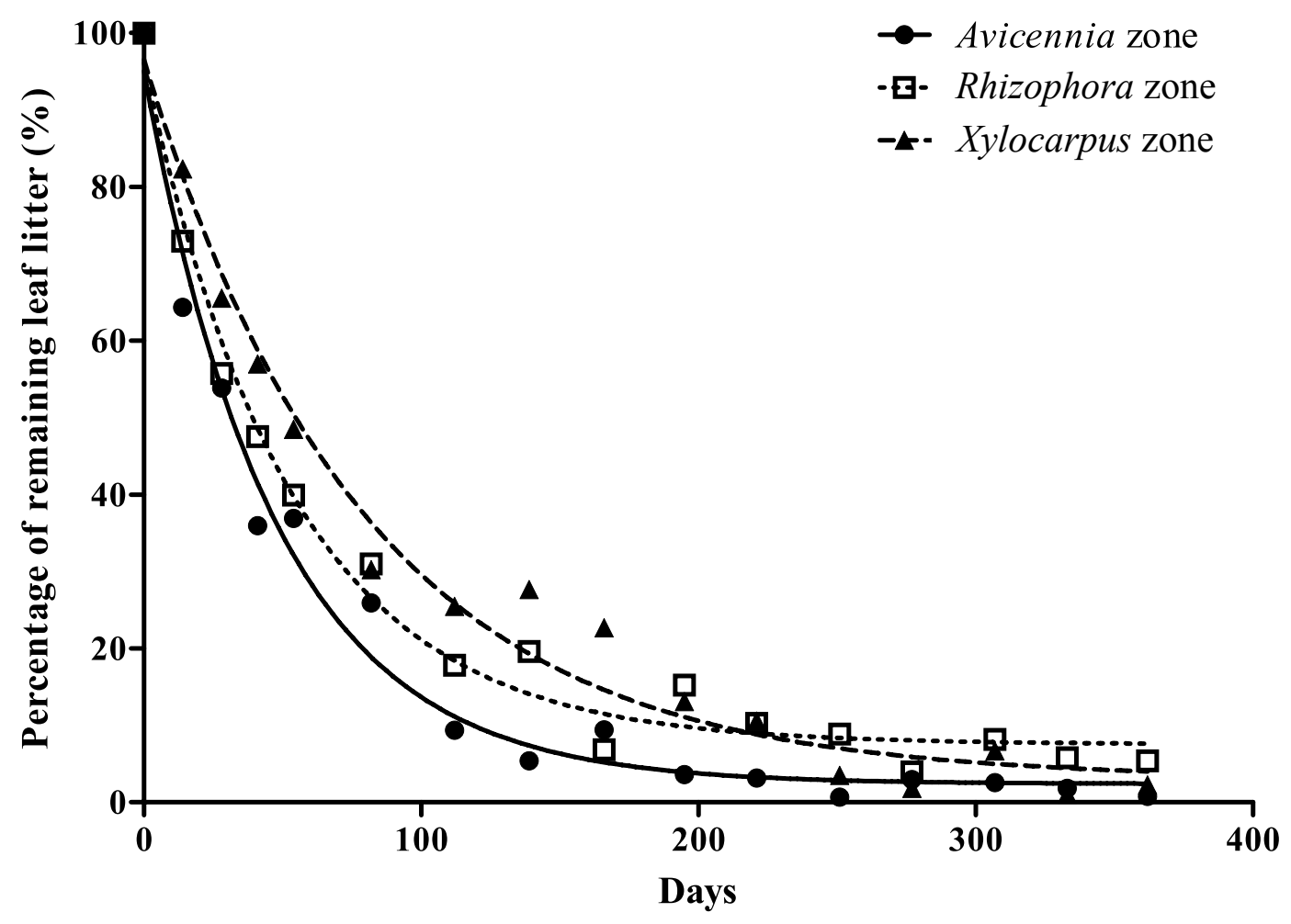

Fig. 4. The percentage of residual leaf litter in the Avicennia ( $\mathbf{O})$, Rhizophora $(\square)$, and Xylocarpus $(\mathbf{\Delta})$ zones. The regression lines for the Avicennia (solid line), Rhizophora (small dashed line), and Xylocarpus (dashed line) zones were significant at $\mathrm{P}<0.01$. 
litter decomposition rate and both physical factors (inundation period and soil temperature) were significant (Spearman's rank; $r=0.99, \mathrm{n}=3, \mathrm{P}<0.01$ ).

\section{$\mathrm{C} / \mathrm{N}$ ratio}

The $\mathrm{C} / \mathrm{N}$ ratio of the initial leaf mixture at the start of the trial (i.e., when collected) was 111.0. That of the residual leaf litter rapidly decreased during the first 54 days of the trial in all three zones (Fig. 5), reaching ratios of 44.7, 41.9, and 51.8 in the Avicennia, Rhizophora, and Xylocarpus zones, respectively. Subsequently, the C/N ratio of all zones slowly decreased until the end of the trial (362 days), at which point the lowest $\mathrm{C} / \mathrm{N}$ ratio occurred in the residual litter from the Avicennia zone (27.0), followed by the residual litter in the Rhizophora (32.9) and Xylocarpus (43.1) zones.
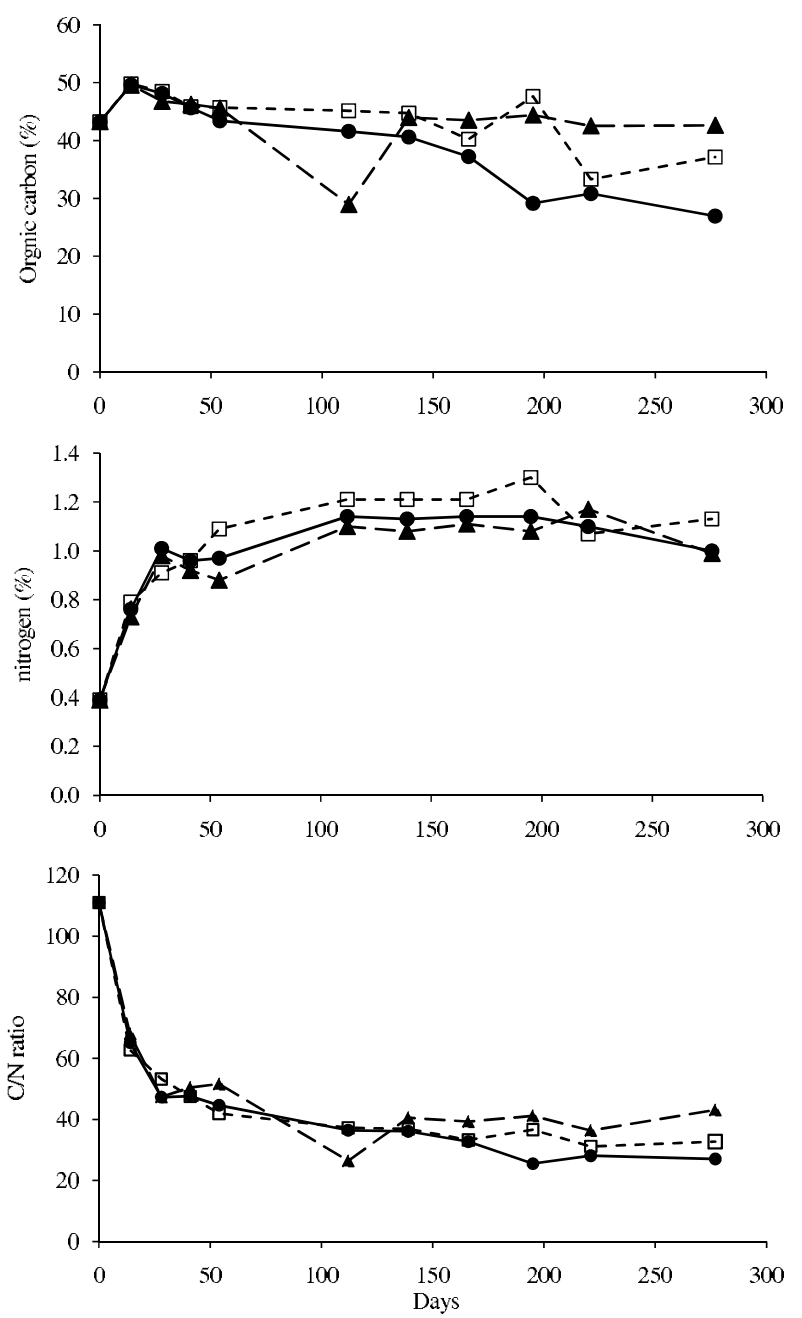

Fig. 5. Organic carbon and nitrogen concentration and the $\mathrm{C} / \mathrm{N}$ ratio of residual leaf litter over time in the

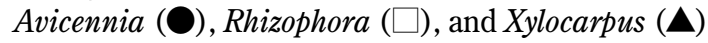
zones.

\section{DISCUSSION}

The rate of leaf-litter decomposition in a forest ecosystem is commonly indicated by the coefficient of the exponential model fitted between the residual litter and time (Mackey and Smail 1996, Ashton et al. 1999). In the present study, the decomposition rates of leaf litter in the three vegetation zones of this mangrove forest ranged between 0.023-0.014. These values were more or less similar to those obtained in other tropical mangrove forests (Table 2). Prior work has revealed that the difference in micro-topography and micro-environment among forest sites are casual physical factors of changes in decomposition rate (Twilley 1995), whilst the species composition of the leaf litter also affected the rate of decomposition by the different leaf morphological characteristics (Robertson 1988, Twilley et al. 1997, Ashton et al. 1999). For example, the leaf blade of Avicennia and Sonneratia is thinner than that of Rhizophora, while the leaf blade of Ceriops is thicker than that of Rhizophora and Bruguiera (Tomlinson 1986). Thus, the thin leaf of Avicennia tends to decompose faster than the thick leaf of Rhizophora, Bruguiera and Ceriops (Tomlinson 1986, Twilley et al. 1986, Robertson 1988, Ashton et al. 1999). Although we used a mixed leaf-litter in our experiment, it was primarily composed of Rhizophora leaves because of the high density of Rhizophora trees in the study site. Accordingly, the decomposition rates in the present study were comparable to that of Rhizophora forest in the same tropical regions (i.e. Boonruang 1978, Ashton et al. 1999), but lower than that of an Avicennia forest in Thailand (Boonruang 1978). The observed decomposition rates were also higher than those measured in a subtropical mangrove forest in Australia (Goulter and Allaway 1979, Mackey and Smail 1996, Dick and Osunkoya 2000), as shown in Table 2.

Leaf litter was lost rapidly during the first 8 weeks of the trial before nearly plateauing at the end of the 362-day trial (Fig. 4). This pattern of decreasing rates of leaf-litter loss with time has been observed in other mangrove forests (Boonruang 1978, Woodroffe 1982, Robertson 1988, Middleton and McKee 2001, Ono et al. 2006) and also coincided with the trend in residual litter $\mathrm{C} / \mathrm{N}$ ratio, which similarly rapidly decreased over the first 54-112 days and then reached a very slow declining rate over the rest of the trial period in all three zones (Fig. 5). The $\mathrm{C} / \mathrm{N}$ ratio of the residual leaf litter was inversely related to the degree of decomposition, likely because of decomposition processes such as the release of organic carbon as a food 
Table 2. Decomposition rates of leaf-litter species in different mangrove forests.

\begin{tabular}{|c|c|c|c|}
\hline Species of leaf litter in litter bag & Site & $K\left(\right.$ day $\left.^{-1}\right)$ & Reference \\
\hline Avicennia marina & Phuket Island, Thailand & 0.035 & Boonruang 1978 \\
\hline A. marina & Sydney, Australia & 0.012 & Goulter and Allaway 1979 \\
\hline \multirow[t]{4}{*}{ A. marina } & Low tidal level zone & $0.009-0.016$ & Mackey and Smail 1996 \\
\hline & Queensland, Australia & & \\
\hline & High tidal level zone & $0.002-0.007$ & \\
\hline & Queensland, Australia & & \\
\hline \multirow[t]{4}{*}{ A. marina } & Landward & 0.001 & Dick and Osunkoya 2000 \\
\hline & New South Wales, Australia & & \\
\hline & Tidal zone & 0.009 & \\
\hline & New South Wales, Australia & & \\
\hline Rhizophora apiculata & Phuket Island, Thailand & 0.017 & Boonruang 1978 \\
\hline R. apiculata & Peninsular Malaysia & 0.016 & Ashton et al. 1999 \\
\hline R. mucronata & Peninsular Malaysia & 0.02 & Ashton et al. 1999 \\
\hline Rhizophora spp. & Guayas River estuary, Ecuador & $0.003-0.016$ & Twilley et al. 1997 \\
\hline Sonneratia alba & Peninsular Malaysia & 0.031 & Ashton et al. 1999 \\
\hline Mixed species & Suratthani, Thailand & 0.025 & Angsupanich and Aksornkoae 1994 \\
\hline Mixed species & Peninsular Malaysia & 0.022 & Ashton et al. 1999 \\
\hline Mixed species & Trat, Thailand & $0.014-0.023$ & This study \\
\hline
\end{tabular}

source for decomposers (Gee and Somerfield 1997, Cannicci et al. 2008, Nagelkerken et al. 2008) and catabolic conversion to $\mathrm{CO}_{2}$ with subsequent release to the atmosphere, whereas nitrogen in the decomposed leaf litter only changed slightly over time (Dick and Osunkoya 2000, Bosire et al. 2005, Ananda et al. 2008). Moreover, Twilley et al. (1986) suggested a reason of the high $\mathrm{C} / \mathrm{N}$ ratio of fallen leaf before entering the decomposition process that mangrove plants can reabsorb or re-translocate nitrogen just prior to leaf fall.

The results showed zonal variation in leaf-litter decomposition among zones. The order of decomposition rates in the three vegetation zones was numerically ranked with Avicennia > Rhizophora > Xylocarpus, whereas the actual weight of leaf litter lost at the end of the trial in the Rhizophora zone was more than that lost from the Xylocarpus zone (Fig. 4). The sharp and rapid decrease of leaf litter in the Avicennia and Rhizophora zones during the first 112 days of the trial led to high values of the coefficient in the exponential model of residual leaf litter and time. Consistent to the order of decomposition rates obtained by the present study, the decomposition of Avicennia marina leaves in the low intertidal zone was faster than that in the high intertidal zone in mangrove forests in Queensland (Mackey and Smail 1996) and New South Wales (Dick and Osunkoya 2000), Australia. Moreover, Ono et al. (2006) found that the decomposition rate of litter on seaward side of mangrove forest was higher than that of on landward side of a mangrove forest in Micronesia, and principally discussed the rapid decomposition on seaward side by leaf leaching and autolysis under constant inundated condition. The inundation condition is related to the length of time during which leaf litter is leached by the tide. Leaf litter is fragmented and then leached (Robertson 1988, Chale 1993, Ashton et al. 1999), which physically enhances the rate of leaf-litter decomposition. In the present study, the forest floor in the low intertidal Avicennia zone was inundated for the longest period of time, rendering its leaf litter softer and more easily leached than the leaf litter of the other zones. Although long period of inundated soil is typically anaerobic conditions (McKee et al. 1988) limiting the activity of microbes and benthic organisms in mangrove forests, Poungparn et al. (2009) revealed a wider range of water table on the river edge than that of inland part. This may allow oxygen rich condition for activity of microbes relating to litter decomposition on the zone of river fringe.

The process of leaf-litter decomposition usually depends on temperature, as higher soil temperature promote microbial activity (Valiela et al. 1985, Witkamp 1966) which is hardly measured in the condition of mangrove. The zonal variation in soil temperature at our study site was related to topography and inundation period (after Poungparn et al. 2009). The figure 3 obviously showed that the water temperature was usually 
higher than that of soil temperature which decreased with increasing distance from the river. The result also indicated that the soil temperature varied significantly among the three zones. The warmer water increased the soil temperature after long inundated period of the zone adjacent to the river (Poungparn et al. 2009).

Although it was suggested that lost litter via the process of decomposition in the mangrove forest was much lower than the lost litter by tidal litter transportation to the sea adjacent to the forest (Ono et al. 2006), the decomposed litter generally releases $\mathrm{CO}_{2}$ because of catabolic metabolism of microbial activities in the decomposition process. According to the residual of leaf litter at the end of the trial of our present study, we calculated $\mathrm{CO}_{2}$ released from the decomposition process as a range of 251.0-264.0 $\mathrm{g} \mathrm{CO}_{2} \mathrm{~m}^{-2} \mathrm{yr}^{-1}$. Recently, Poungparn et al. (2009) explored $\mathrm{CO}_{2}$ emission via soil respiration in the mangrove forest of the Trat River, Thailand. Carbon dioxide released from the decomposition process obtained by the present study shared 26.2-40.0\% of $\mathrm{CO}_{2}$ emission from soil respiration measured by Poungparn et al. (2009) in the same study site. A value of $37 \%$ was reported as a contribution of $\mathrm{CO}_{2}$ emission from respiration in the litter layer to total soil $\mathrm{CO}_{2}$ efflux in a tropical terrestrial forest (Zimmermann et al. 2009), it was in the range of $\mathrm{CO}_{2}$ efflux via leaf-litter decomposition obtained by the present study. This consistency implies the role of released $\mathrm{CO}_{2}$ via leaf-litter decomposition in the tropical region.

In conclusion, the decomposition rate gradient from leaf litter was elucidated the three main vegetation zones located from the river edge to the inland region of secondary mangrove forest. The causative factors of inundation time and soil temperature contributed to this zonal variation in leaf-litter decomposition.

ACKNOWLEDGMENTS We would like to thank the staff of the Plant Ecology Research Unit of Chulalongkorn University and the Mangrove Forest Learning and Development Center No. 1 at Trat Province, Thailand, for their help in the field. The Thailand Research Fund and Graduate Thesis Grant of Chulalongkorn University provided financial support.

\section{REFERENCES}

Aksornkoae S. 1975. Structure, regeneration and productivity of mangroves in Thailand. Thesis of a doctor degree, Michigan State University, USA.
Aksornkoae S. 1976. Structure of mangrove forest at Amphoe Khlung, Changwat Chantaburi, Thailand. Kasetsart University, Forest Bulletin 38.

Aksornkoae S, Khemnark C. 1980. Nutrient cycling in mangrove forest of Thailand. In: Soepadmo E, Rao AN, Macintosh DJ (eds) Proceedings of the Asian Symposium on Mangrove Environment Research and Management. University of Malaya, Kuala Lumper. 545-557.

Alhamad L, Arakaki S, Hagihara A. 2004. Decomposition of leaf litter of four tree species in a subtropical evergreen broad-leaved forest, Okinawa Island, Japan. Forest Ecology and Management 202: 1-11.

Ananda K, Sridhar KR, Raviraja NS, Bärlocher F. 2008. Breakdown of fresh and dried Rhizophora mucronata leaves in a mangrove of Southwest India. Wetlands Ecology and Management 16: 1-9.

Angsupanich S, Aksornkoae S. 1994. Decomposition of Mangrove Leaf Litter in Phang-nga Bay, Southern Thailand. Tropics 4: 41-47.

Ashton EC, Hogarth PJ, Ormand R. 1999. Breakdown of mangrove leaf litter in a managed mangrove forest in Peninsular Malaysia. Hydrobiologia 413: 77-88.

Boonruang P. 1978. The degradation rates of mangrove leaves of Rhizophora apiculata (B1.) and Avicennia marina (Forsk Vierh.) at Phuket Island, Thailand. Phuket Marine Biology Center Research Bulletin 26: 1-7.

Bosire JO, Dahdouh-Guebas F, Kairo JG, Kazungu J, Dehairs F, Koedam N. 2005. Litter degradation and $\mathrm{CN}$ dynamics in reforested mangrove plantations at Gazi Bay, Kenya. Biological Conseravetion 126: 287295.

Boulton AJ, Boon PI. 1991. A review of methodology used to measure leaf litter decomposition in lotic environments: time to turn over an old leaf. Australian Journal of Marine and Freshwater Research 42: 1-43.

Cannicci S, Burrows D, Fratini S, Smith TJ, Offenberg J, Dahdouh-Guebas F. 2008. Faunal impact on vegetation structure and ecosystem function in mangrove forests: A review. Aquatic Botany 89: 186200.

Chale FMM. 1993. Degradation of mangrove leaf litter under aerobic conditions. Hydrobiology 217: 17711783.

Dick T, Osunkoya OO. 2000. Influence of tidal restriction floodgates on decomposition of mangrove litter. Aquatic Botany 86: 273-280.

Gee JM, Somerfield PJ. 1997. Do mangrove diversity and 
leaf litter decay promote meiofaunal diversity? Journal of Experimental Marine Biology and Ecology 218: 13-33.

Goulter PFE, Allaway WG. 1979. Litter fall and Decomposition in a Mangrove Stand (Avicennia marina) in Middle Harbour, Sydney. Australian Journal of Marine and Freshwater Research 30: 541546.

Hoq ME, Islam ML, Paul HK, Ahmed SU. 2002. Decomposition and seasonal changes in nutrient constituents in mangrove litter of Sundarbans mangrove, Bangladesh. Indian Journal of Marine Sciences 31: 130-135.

Imgraben S, Dittmann S. 2008. Leaf litter dynamics and litter consumption in two temperate South Australian mangrove forest. Journal of Sea Research 59: 83-93.

Kurz C, Coûteaux MM, Thiéry JM. 2000. Residence time and decomposition rate of Pinus pinaster needles in a forest floor from direct field measurements under a Mediterranean climate. Soil Biology and Biochemistry 32: 1197-1206.

Liu Q, Peng SL, Bi H, Zang HY, Li ZA, Ma WH, Li NY. 2005. Decomposition of leaf litter in tropical and subtropical forests of Southern China. Journal of Tropical Forest Science 17: 543-556.

Lugo AE, Snedaker SC. 1974. The ecology of mangroves. Annual Review of Ecology and Systematics 5: 39-64.

Mackey AP, Smail G. 1996. The decomposition of mangrove litter in a subtropical mangrove forest. Hydrobiologia 332: 93-98.

Macnae W. 1967. Zonation within mangrove associated with estuaries in North Queensland. Estuaries 83: 432-441.

McKee KL, Mendelssohn IA, Hester MW. 1988. Reexamination of pore water sulfide concentrations and redox potentials near the aerial roots of Rhizophora mangle and Avicennia germinans. American Journal of Botany 75: 1352-1359.

Middleton BA, McKee KL. 2001. Degragation of mangrove tissues and implications for peat formation in Belizean island forests. Journal of Ecology 89: 818-828.

Moretto AS, Distel RA. 2003. Decomposition of and nutrient dynamics in leaf litter and roots of $P o a$ ligularis and Stipa gyneriodes. Journal of Arid Environments 55: 503-514.

Nagelkerken I, Blaber SJM, Bouillon S, Green P, Haywood M, Kirton LG, Meynecke JO, Pawlik J, Penrose HM, Sasekumar A, Somerfield PJ. 2008.
The habitat function of mangroves for terrestrial and marine fauna: A review. Aquatic Botany 89: 155-185.

Olson JS. 1963. Energy storage and the balance of producers and decomposers in ecological system. Ecology 42: 322-330.

Ono K, Fujimo K, Hiraide M, Lihpai S, Tabuchi R. 2006. Aboveground litter production, accumulation, decomposition and tidal transportation of coral reeftype mangrove forest on Pohnpei Island, Federated States of Micronesia. Tropics 15: 75-84.

Patanaponpaiboon P. 1979. Structure of Mangrove Forest at Amphoe Khao. Samin, Trat. Thesis of a master degree, Chulalongkorn University, Bangkok.

Poungparn S, Komiyama A, Tanaka A, Sangtiean T, Maknual C, Kato S, Tanapermpool P, Patanaponpaiboon P. 2009. Carbon dioxide emission through soil respiration in a secondary mangrove forest of eastern Thailand. Journal of Tropical Ecology 25: 393-400.

Robertson AI. 1988. Decomposition of mangrove leaf litter in tropical Australia. Journal of Experimental Marine Biology 116: 235-247.

Smith TJ. 1992. Forest structure. In: Tropical mangrove ecosystems, coastal and estuarine studies (eds. Robertsons, A.I. \& Alongi, D.N.), pp. 101-136. American Geophysical Union, Washington DC.

Tomlinson PB. 1986. The Botany of Mangroves. Cambridge University Press, London.

Twilley RR, Lugo AE, Patterson-Zucca C. 1986. Litter production and turnover in Basin mangrove forests in southwest Florida. Ecology 67: 670-683.

Twilley RR. 1995. Properties of mangrove ecosystems related to the energy signature of coastal environments. In: Maximum power: the ideas and applications of H.T. Odum (ed. Hall, C.A.S.), pp. 43-62. University Press of Colorado, Niwot.

Twilley RR, Pozo M, Garcia VH, Rivera-Monroy VH, Zambrano R, Bodero A. 1997. Litter dynamics in riverine mangrove forests in the Guayas River estuary, Ecuador. Oecologia 111: 109-122.

Valiela I, Teal JM, Allen SD, Etten RV, Goehringer D, Volkmann S. 1985. Decomposition in salt marsh ecosystems: the phases and major factors affecting disappearance of above-ground organic matter. Journal of Experimental Marine Biology 89: 29-54.

Watson JG. 1928. Mangrove forests of the Malayan Peninsula. Malayan Forest Records 6: 1-275.

Witkamp M. 1966. Decomposition of leaf litter in relation to environment, microflora and microbial respiration. Ecology 47: 194-201. 
Woodroffe CD. 1982. Litter production and decomposition in the New Zealand mangrove Avicennia marina var. resinifer. New Zealand Journal of Marine and Freshwater Research 16: 179-188.

Zhou G, Guan L, Wei X, Tang X, Liu S, Lie J, Zhang D, Yan J. 2008. Factors influencing leaf litter decomposition: an intersite decomposition experiment across China. Plant and Soil 311: 61-72.

Zimmermann M, Meir P, Bird M, Malhi Y, Ccahuana A. 2009. Litter contribution to diurnal and annual soil respiration in a tropical montane cloud forest. Soil Biology \& Biochemistry 41: 1338-1340.

Received $12^{\text {th }}$ Oct. 2010

Accepted 22 $2^{\text {nd }}$ Jun. 2011 